\title{
Study of Soybean Oil Hydrolysis Catalyzed by Thermomyces lanuginosus Lipase and Its Application to Biodiesel Production via Hydroesterification
}

\author{
Elisa d'Avila Cavalcanti-Oliveira, ${ }^{1}$ Priscila Rufino da Silva, ${ }^{1,2}$ Alessandra Peçanha Ramos, ${ }^{1,2}$ \\ Donato Alexandre Gomes Aranda, ${ }^{2}$ and Denise Maria Guimarães Freire ${ }^{1}$
}

${ }^{1}$ Laboratório de Biotecnologia Microbiana (LaBiM), Centro de Tecnologia, Instituto de Química, lab. 549-1, Universidade Federal do Rio de Janeiro, CEP 21945-970, Rio de Janeiro, RJ, Brazil

${ }^{2}$ Laboratório de Tecnologia Verde (GreenTec), Centro de Tecnologia, Escola de Química, lab. 211, Universidade Federal do Rio de Janeiro, CP. 68542, CEP 21945-970 Rio de Janeiro, RJ, Brazil

Correspondence should be addressed to Denise Maria Guimarães Freire, freire@iq.ufrj.br

Received 20 July 2010; Revised 21 September 2010; Accepted 5 October 2010

Academic Editor: Sulaiman Al-Zuhair

Copyright ( $) 2011$ Elisa d'Avila Cavalcanti-Oliveira et al. This is an open access article distributed under the Creative Commons Attribution License, which permits unrestricted use, distribution, and reproduction in any medium, provided the original work is properly cited.

\begin{abstract}
The process of biodiesel production by the hydroesterification route that is proposed here involves a first step consisting of triacylglyceride hydrolysis catalyzed by lipase from Thermomyces lanuginosus (TL 100L) to generate free fatty acids (FFAs). This step is followed by esterification of the FFAs with alcohol, catalyzed by niobic acid in pellets or without a catalyst. The best result for the enzyme-catalyzed hydrolysis was obtained under reaction conditions of $50 \%$ (v/v) soybean oil and $2.3 \%$ (v/v) lipase (25 U/mL of reaction medium) in distilled water and at $60^{\circ} \mathrm{C}$; an $89 \%$ conversion rate to FFAs was obtained after 48 hours of reaction. For the esterification reaction, the best result was with an FFA/methanol molar ratio of 1:3, niobic acid catalyst at a concentration of $20 \%$ (w/w FFA), and $200^{\circ} \mathrm{C}$, which yielded $92 \%$ conversion of FFAs to soy methyl esters after 1 hour of reaction. This study is exceptional because both the hydrolysis and the esterification use a simple reaction medium with high substrate concentrations.
\end{abstract}

\section{Introduction}

Biodiesel is composed of esters of fatty acids with a shortchain alcohol (methanol or ethanol). It is an alternative fuel obtained from renewable sources such as vegetable oils and animal fats and emits fewer atmospheric pollutants than petroleum diesel. Because its properties are similar to those of petroleum diesel, biodiesel can be used directly in diesel engines without extensive mechanical modifications or maintenance expenses [1].

Biodiesel production by the hydroesterification route occurs in two stages. First, all the material is hydrolyzed to free fatty acids (FFAs) and glycerol. Next, the FFAs are separated and esterified with a short-chain alcohol, generating biodiesel and water. The hydroesterification process has some advantages over the alkaline transesterification process, which is the method that is most often used industrially. In the latter, a high-quality oil or fat is transesterified with methanol in the presence of $\mathrm{NaOH}, \mathrm{KOH}$, or sodium methoxide to produce biodiesel and glycerol [2]. However, the disadvantage of the alkaline transesterification route is the high final cost of the biodiesel, mainly because of the price of high-quality oil/fat (which comprises around $80 \%$ of the biodiesel cost) and the low selling price of glycerol (by-product). For the alkaline transesterification process, the raw material must be free of FFAs and water; otherwise, soap is formed, resulting in neutralization of the catalyst and difficulty of purification. Also, the glycerol by-product is contaminated with the salt resulting from the catalyst neutralization and methanol and brings a low price [3-7]. One advantage of hydroesterification for alkaline transesterification is the generation of a glycerol without 
contact with methanol (which is highly toxic), and this product can be a higher-value food-grade glycerol. Another major advantage is the ability to employ as raw material oils and fats with high concentrations of FFAs and water, which are considered low quality and therefore have a much lower market price [2]. Economic analysis has shown that the hydroesterification process can be as attractive as or more so than the alkaline transesterification process for biodiesel production [5].

Minami and Saka [8] studied a catalyst-free hydroesterification process to obtain biodiesel, involving a subcritical hydrolysis and a supercritical esterification with methanol, and obtained conversion rates above $90 \%$ in the two steps (both conducted at a temperature of $270^{\circ} \mathrm{C}$ and a pressure of $20 \mathrm{MPa}$ ). ("Supercritical" refers to a condition above the critical temperature and pressure of the reagent.) Investigations of biodiesel production by hydroesterification using niobic acid in pellets as a catalyst in hydrolysis [9] as well as in the esterification reaction [911] have reported high conversion rates (over 90\%) in both stages.

Enzymatic hydrolysis (catalyzed by lipases, E.C. 3.1.1.3) has some advantages over chemical or thermal hydrolysis, because enzyme reactions require lower temperatures, which prevents the degradation of products and reduces energy costs. Furthermore, enzymes are biodegradable and consequently are less polluting than chemical catalysts. The main disadvantages of enzyme catalysis are the longer reaction time and the higher cost of the biocatalysts [12]. Enzymatic esterification is more complicated, because often the enzyme is deactivated by the alcohol used as a substrate [13]. The use of a heterogeneous acid catalyst in this step is very interesting, since it is not deactivated by short-chain alcohol, it can be easily separated from the product and reused, and acid catalysts are quite effective in converting FFAs to esters $[6,14]$.

Talukder et al. [15] studied the process of enzymechemical hydroesterification with lipase from Candida rugosa and the chemical catalyst Amberlyst 15 (acidic sulfonated styrene-divinylbenzene ion-exchange resin) and obtained complete conversions in the enzymatic hydrolysis and chemical esterification. Our group also studied enzymechemical hydroesterification, but employed as catalysts the lipase of germinated seeds of Jatropha curcas and niobic acid in pellets, and also obtained high conversion rates [11].

The majority of enzymatic hydrolysis procedures reported in the literature are impractical because they use a low oil content in the reaction, a high concentration of lipase, or a buffer, organic solvent, and emulsifier, all of which increase costs and complicate the purification step. Therefore, we believe that it is important to search for reaction media that are as simple as possible and use higher substrate concentrations.

The present study evaluated biodiesel production using hydroesterification, with the hydrolysis reaction catalyzed by the lipase from Thermomyces lanuginosus (TL 100L) and the esterification reaction catalyzed by niobic acid in pellets or without a catalyst, using simple reaction media with a
TABLE 1: Coded levels and real values of tested variables in the CCRD.

\begin{tabular}{lccccc}
\hline Variables & -1.68 & -1 & 0 & 1 & 1.68 \\
\hline $\begin{array}{l}\text { Temperature } \\
\left({ }^{\circ} \mathrm{C}\right)\end{array}$ & 47 & 50 & 55 & 60 & 63 \\
$\begin{array}{l}\text { Lipase } \\
\text { concentration } \\
\left(\% \mathrm{v} / \mathrm{v}^{*}\right)\end{array}$ & 0.5 & 2.3 & 5 & 7.7 & 9.5 \\
$\begin{array}{l}\text { Oil } \\
\text { concentration } \\
\left(\% \mathrm{v} / \mathrm{v}^{*}\right)\end{array}$ & 55 & 62 & 73 & 84 & 91 \\
\hline
\end{tabular}

* volume of oil + buffer.

high substrate concentration. The TL 100L lipase is sold by Novozymes and is recommended by this company for the hydrolysis of triacylglycerides [16].

\section{Material and Methods}

2.1. Catalysts. The liquid lipase from Thermomyces lanuginosus (Lipozyme TL 100L) was purchased from Novozymes. This lipase is recommended by Novozymes for hydrolysis and is a "food-grade" enzyme [16]. The lipase TL 100L showed activity of $1064 \pm 31 \mathrm{U} / \mathrm{mL}$ determined on soybean oil $(5 \%$ w/v) emulsified with Triton X-100 (25\% w/v) in sodium phosphate buffer $0.05 \mathrm{M}, \mathrm{pH} 7.0(50 \% \mathrm{v} / \mathrm{v})$, and distilled water, at $37^{\circ} \mathrm{C}, 200 \mathrm{rpm}$; the FFAs produced were titrated with $0.04 \mathrm{~N} \mathrm{NaOH}$ until $\mathrm{pH} 11$. One lipase activity unit (U) was defined as the amount of enzymes that produced $1 \mu \mathrm{mol}$ FFA per min under the assay conditions.

The chemical catalyst used was niobic acid in pellets (HY340 , surface area $80 \mathrm{~m}^{2} / \mathrm{g}$, and pore volume $\left.0.6 \mathrm{~cm}^{3} / \mathrm{g}\right)$ purchased from CBMM (Companhia Brasileira de Metalurgia e Mineração).

2.2. Enzymatic Hydrolysis of Soybean Oil. The reactions were carried out with a volume of $10 \mathrm{~mL}$, in thermostated reactors, under magnetic stirring. The reaction medium was composed of soybean oil, $10 \mathrm{mM}$ sodium phosphate buffer ( $\mathrm{pH}$ 8.0), and lipase TL 100L. The concentrations of soybean oil and lipase, as well as the temperature and reaction time were alternated during the study, and the conditions used in each experiment are described below. At the end of the reaction, the oil was extracted with hexane and concentrated in a rotary evaporator, and then the concentration of FFAs was determined from the final acidity of the oil.

A Central Composite Rotatable Design (CCRD) was used to investigate the conversion of the hydrolysis reaction. The levels of the variables studied are shown in Table 1. The results were analyzed using Statistica 7.0.

The hydrolysis reactions to produce the FFAs to be esterified (results of Section 3.2) were conducted with $1 \mathrm{~L}$ volume, in a thermostated reactor, under mechanical stirring, because a larger volume was necessary for the esterification reactor. All other conditions were as described above. 
TABLE 2: CCRD matrix and the results of soybean oil hydrolysis by lipase TL 100L. The reactions were carried out in $10 \mathrm{mM}$ sodium phosphate buffer ( $\mathrm{pH} 8.0$ ) for 19 hours.

\begin{tabular}{lcccc}
\hline Assay & Temperature $\left({ }^{\circ} \mathrm{C}\right)$ & Concentration of lipase $(\% \mathrm{v} / \mathrm{v})$ & Concentration of oil $(\% \mathrm{v} / \mathrm{v})$ & Final concentration of FFAs $(\% \mathrm{w} / \mathrm{w})$ \\
\hline 1 & 50 & 2.3 & 62 & 80.4 \\
2 & 60 & 2.3 & 62 & 85.4 \\
3 & 50 & 7.7 & 62 & 85.6 \\
4 & 60 & 7.7 & 62 & 85.6 \\
5 & 50 & 2.3 & 84 & 66.9 \\
6 & 60 & 2.3 & 84 & 72.5 \\
7 & 50 & 7.7 & 84 & 74.3 \\
8 & 60 & 7.7 & 84 & 71.7 \\
9 & 47 & 5.0 & 73 & 78.6 \\
10 & 63 & 5.0 & 73 & 81.0 \\
11 & 55 & 0.5 & 73 & 70.1 \\
12 & 55 & 9.5 & 73 & 81.7 \\
13 & 55 & 5.0 & 55 & 86.8 \\
14 & 55 & 5.0 & 91 & 66.1 \\
15 & 55 & 5.0 & 73 & 82.0 \\
16 & 55 & 5.0 & 73 & 82.1 \\
17 & 55 & 5.0 & 73 & 84.0 \\
18 & 55 & 5.0 & 73 & 83.1 \\
\hline
\end{tabular}

2.3. Esterification of Free Fatty Acids. The esterification reactions were carried out using the optimum conditions described by Lima [9]: molar ratio FFAs/alcohol of 1:3 for methanol and 1:4 for ethanol; niobic acid catalyst in pellets at a concentration of $20 \%$ (w/w of FFAs), or without catalyst; temperature $200^{\circ} \mathrm{C}$; pressure $350 \mathrm{psi}$; and reaction time 1 hour. At the end of the reaction, the catalyst was removed by filtration and the product was held at $110^{\circ} \mathrm{C}$ for 5 minutes to eliminate the residual alcohol and water formed. The conversion of FFAs to alkyl esters was determined by titration of the remaining FFAs (acidity).

2.4. Determination of Acidity. The acidity was determined by titration of FFAs with $0.25 \mathrm{~N} \mathrm{NaOH}$, and the result was expressed in grams of FFAs per $100 \mathrm{~g}$ of the sample [9].

\section{Results and Discussion}

3.1. Enzymatic Hydrolysis of Soybean Oil. Initially, the reaction conditions for the hydrolysis of soybean oil catalyzed by lipase TL 100L were investigated. A previous experimental design (data not shown) indicated that higher conversion rates could be obtained by fixing the sodium phosphate buffer in $10 \mathrm{mM} / \mathrm{pH} 8.0$ and optimizing the temperature and the concentrations of lipase and soybean oil. This optimization was carried out using a Central Composite Rotatable Design (CCRD). The design matrix and the results obtained are shown in Table 2.

The best conversion of FFAs was obtained in assay 13 , in the lowest concentration of soybean oil $(55 \%)$, at $55^{\circ} \mathrm{C}$ and with $5 \%$ of the biocatalyst (corresponding to $53 \mathrm{U} / \mathrm{mL}$ of reaction medium). Based on the statistical analysis of the results, an empirical model was constructed (1) to describe the variation in the FFAs concentration as a function of temperature $(T)$, lipase concentration $(L)$, and oil concentration $(O)$. For the model construction, variables with $P$-values lower than .05 were considered statistically significant (Figure 1). The interactions between temperature and oil concentration and between lipase concentration and oil concentration were not statistically significant and were not included in the model (1).

$$
\begin{aligned}
\text { FFA }(\% \mathrm{w} / \mathrm{w})= & 82.76+1.76 T-1.8 T^{2}+4.62 L-4.56 L^{2} \\
& -12.660-4.17 O^{2}-3.3 T^{*} L .
\end{aligned}
$$

The percentage of variance explained by the model was satisfactory $\left(R^{2}=0.98\right)$, indicating that the model had a good adjustment to the experimental data, as observed in Figure 2

Figures 3, 4, and 5 show the contour plots of the concentrations of FFAs obtained by the model of (1).

As apparent from Figure 3, the best conversion rates should be obtained at temperatures between $50^{\circ} \mathrm{C}$ and $60^{\circ} \mathrm{C}$, and higher temperatures require lower lipase concentrations. In the literature, there is no consensus about the optimum reaction temperature for $T$. lanuginosus lipase. While some studies have found values of $37^{\circ} \mathrm{C}$ [17] and $40^{\circ} \mathrm{C}$ [18], other authors have obtained values of $50^{\circ} \mathrm{C}[19]$ and $55^{\circ} \mathrm{C}$ $[20,21]$. The behavior observed in Figure 3, that higher temperatures require lower lipase concentrations to obtain the same conversion rate, may be related to a higher enzyme activity at $60^{\circ} \mathrm{C}$ in these reaction conditions; consequently, less lipase is needed at higher temperatures because the enzyme is more active. Another possibility is related to 


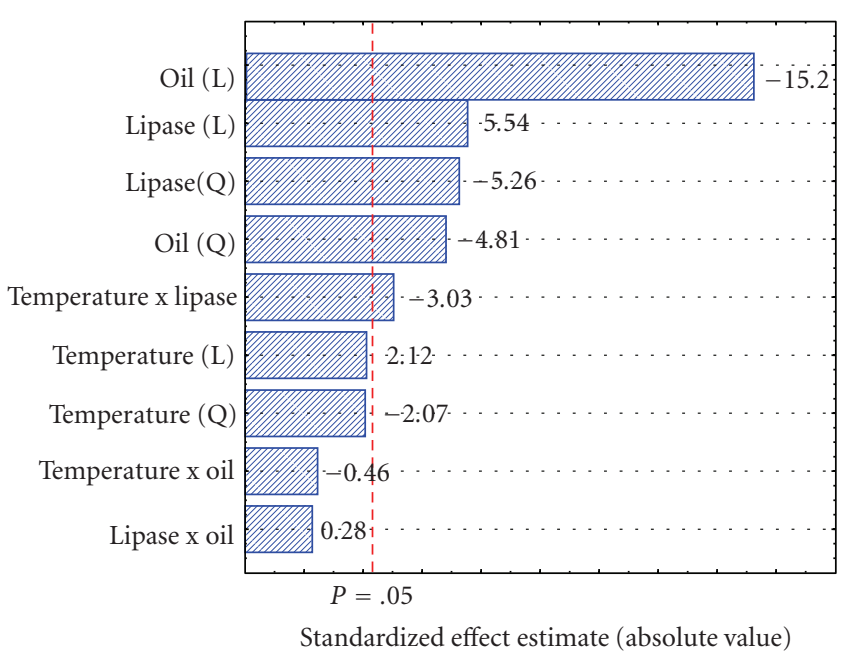

FIGURE 1: Pareto graph showing the effects of different variables on the concentration of FFAs, at the CCRD.

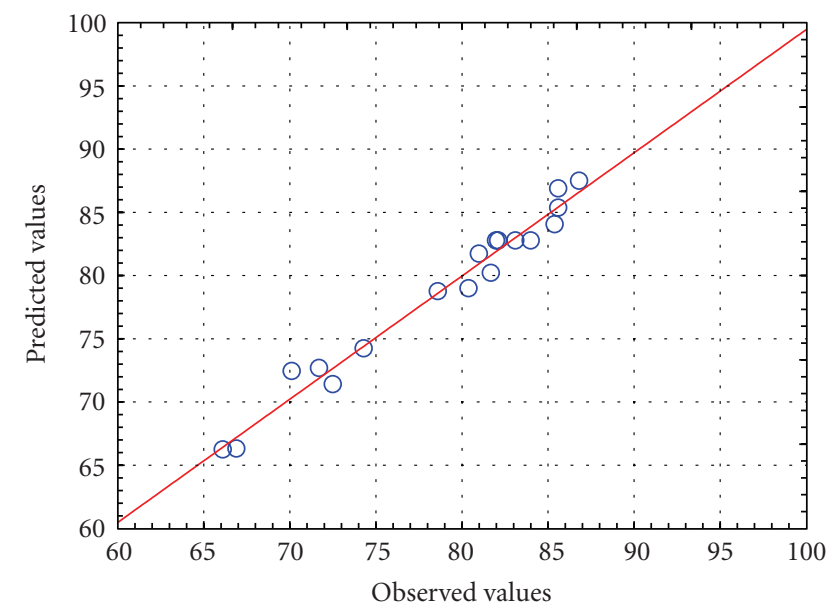

FIGURE 2: Graph of the values of FFA concentrations (\%) predicted by the model, versus values observed experimentally.

increased acyl migration, since this lipase is 1,3-specific and therefore complete hydrolysis of triglyceride depends on the migration of the acyl radical in position 2 to positions 1,3 [22]. Li et al. [23] observed that the increase in temperature increased the acyl migration in their experiments without an enzyme: when they changed the incubation temperature of $30^{\circ} \mathrm{C}$ to $55^{\circ} \mathrm{C}$, the half-life of 1,2-diacylglycerol decreased 10 -fold and the half-life of 2-monoacylglycerol decreased 6fold. For the next experiments, we selected the temperature of $60^{\circ} \mathrm{C}$ since it gave the highest conversion rate with a lower enzyme concentration (Figure 3 ).

As can be seen in Figure 4, the model indicated that the best conversions at $60^{\circ} \mathrm{C}$ should be obtained with concentrations of lipase between $4 \%$ and $8 \%$. The existence of an optimum enzyme concentration range may be explained by two factors: at concentrations lower than $4 \%$, more enzyme may favor the accessibility of a large amount of reactants to the active sites, and at concentrations above
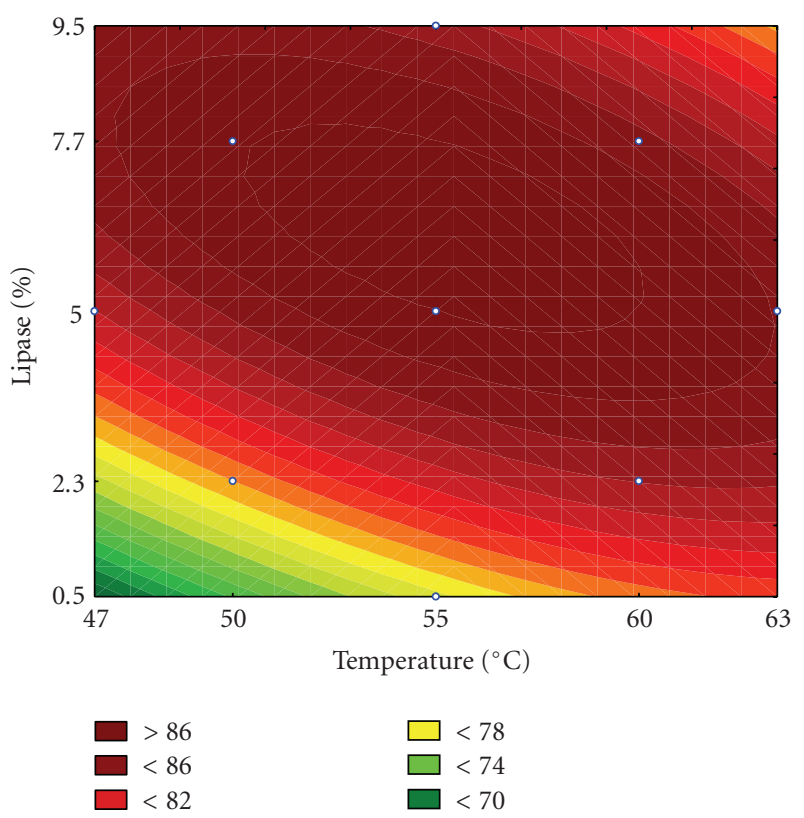

FIgURE 3: Contour plot for FFAs concentration as a function of lipase content and temperature, at an oil concentration of $62 \%$.

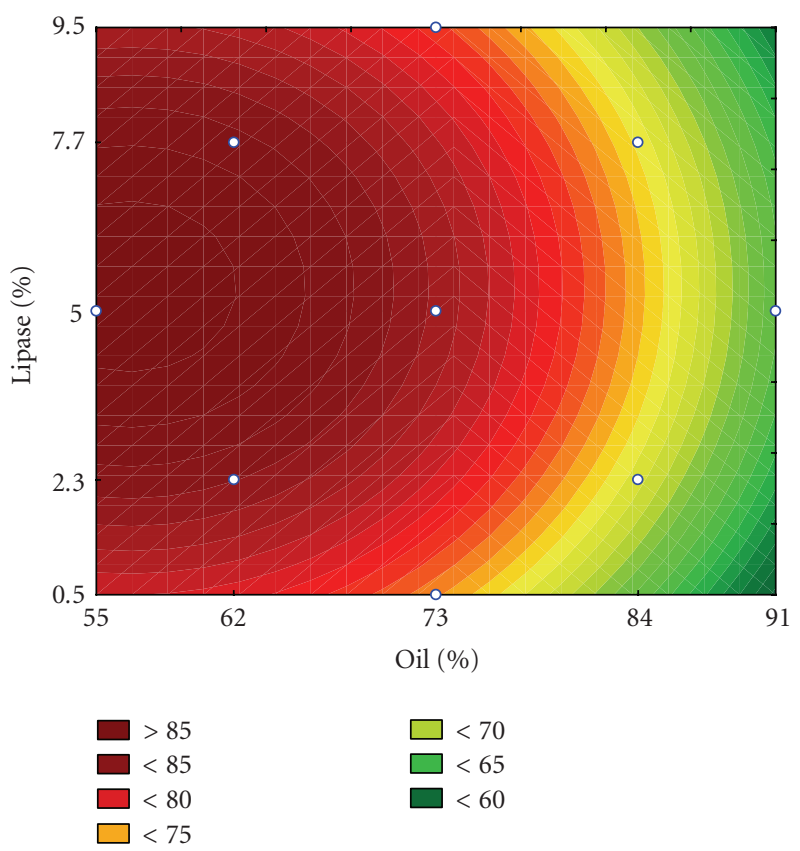

FIgURE 4: Contour plot for FFAs concentration as a function of lipase content and oil concentration, at $60^{\circ} \mathrm{C}$.

$8 \%$, dimers with lower activity may be forming. FernandezLafuente [22] reported a strong tendency of Thermomyces lanuginosus lipase to dimer formation through the union of two molecules of lipase in the regions of their active centers. This dimer is more stable than the monomer; however, it has lower activity [22]. We opted for a lipase concentration of $2.3 \%$, since this concentration also gives good results 


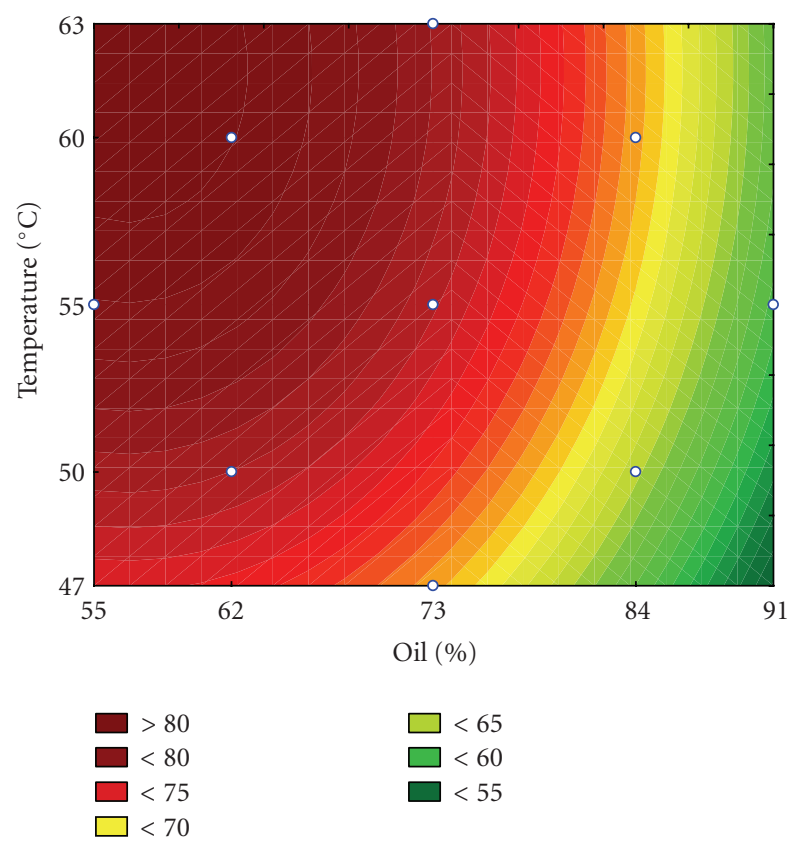

FIgURE 5: Contour plot for FFAs concentration as a function of temperature and oil concentration, for a lipase content of $2.3 \%$.

(Figure 4) and reduces expenses with the biocatalyst in the process.

For a lipase concentration of $2.3 \%$, the model showed the highest conversion rates with oil concentrations lower than $62 \%$ and temperatures higher than $58^{\circ} \mathrm{C}$, as illustrated in Figure 5. The higher conversion rates for lower substrate concentrations were expected, because there are more substrate molecules present to access the active sites of enzymes.

In the conditions selected based on the CCRD $\left(60^{\circ} \mathrm{C}\right.$; $2.3 \%$ lipase; $62 \%$ oil), reaction kinetics were carried out in a simple batch and in a fed-batch of enzyme, as shown in Figure 6 . The fed-batch of enzyme was chosen for evaluation based on the observation of Jurado et al. [19] that after only 30 minutes at $60^{\circ} \mathrm{C}$, the $\mathrm{T}$. lanuginosus lipase lost $13 \%$ of its activity.

Our results in Figure 6 showed very similar reaction kinetics for the simple batch and fed-batch of enzymes (reaching $86 \pm 0.3 \%$ and $83 \pm 2.0 \%$ FFAs after 24 hours, resp.); lipase hydrolytic activity could be observed after 24 hours in the simple batch, showing that the enzyme was not sufficiently deactivated to compromise the reaction. Other investigators have also observed that the lipase from $T$. lanuginosus is capable of maintaining its activity at elevated temperatures such as $50^{\circ} \mathrm{C}-60^{\circ} \mathrm{C}$, with maximum activity near $\mathrm{pH} 9$ [22]. This thermostability was expected, since T. lanuginosus is a thermophilic fungus that produces other thermostable enzymes [24-28].

We also investigated the utilization of lower concentrations of soybean oil, in an attempt to attain higher concentrations of FFAs, as indicated in Figure 5. The results of the reactions with lower oil concentrations are shown in Figure 7.

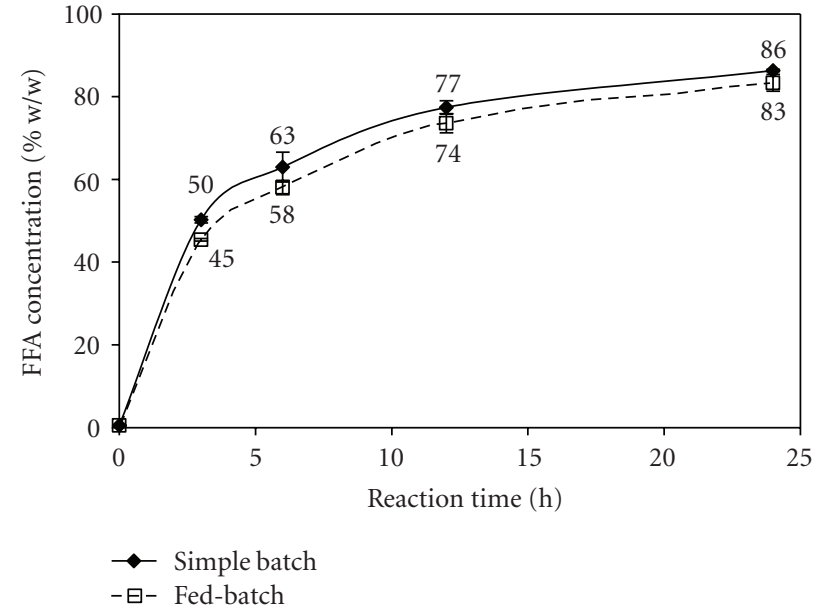

FIGURE 6: Reaction kinetics of simple batch and fed-batch hydrolysis of soybean oil by TL 100L lipase. The reaction conditions were $2.3 \%$ $(\mathrm{v} / \mathrm{v})$ lipase (for the fed-batch this volume of enzyme was divided into 3 equal parts that were added at times zero, 6, and 12 hours), $62 \%(\mathrm{v} / \mathrm{v})$ soybean oil, $10 \mathrm{mM}$ buffer $(\mathrm{pH} 8.0)$, at $60^{\circ} \mathrm{C}$, for 24 hours.

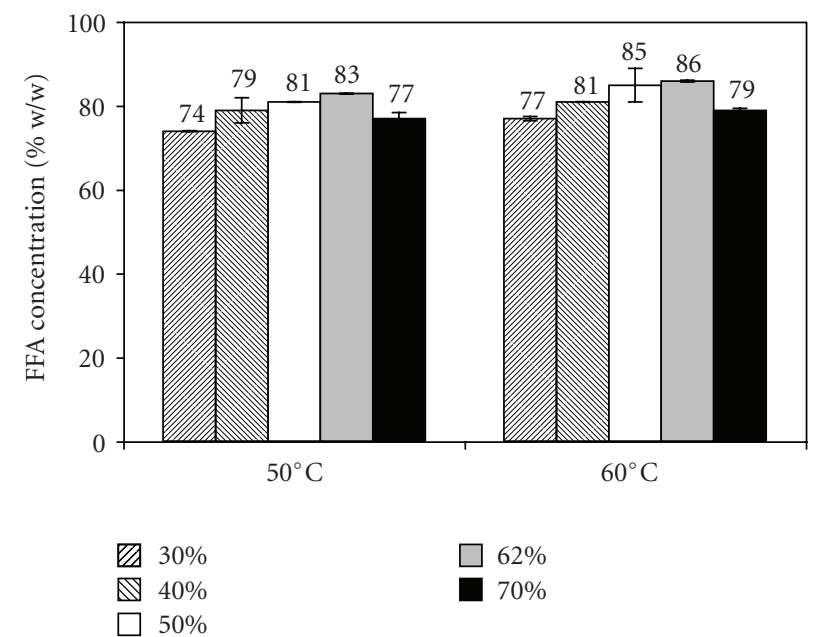

FIGURE 7: Effect of oil concentration on the soybean oil hydrolysis reaction catalyzed by lipase TL 100L. The reactions were conducted with $2.3 \%(\mathrm{v} / \mathrm{v})$ lipase, with different concentrations of soybean oil, in $10 \mathrm{mM}$ phosphate buffer, $\mathrm{pH} 8.0,50^{\circ} \mathrm{C}$, or $60^{\circ} \mathrm{C}$, for 24 hours.

One can observe in Figure 7 that the best conversions were obtained for reactions conducted with $50 \%$ and $62 \%$ $(\mathrm{v} / \mathrm{v})$ of oil at $60^{\circ} \mathrm{C}$. Although the lower rate of conversion at oil concentrations below 50\% was unexpected, it was previously observed by Talukder et al. [7] in the hydrolysis reaction of crude palm oil catalyzed by Candida rugosa lipase.

The best concentrations of soybean oil $(50 \%$ and $62 \%$ oil at $60^{\circ} \mathrm{C}$ ) (Figure 7) were evaluated over a longer reaction time. For the reaction carried out with $50 \%(\mathrm{v} / \mathrm{v})$ soybean oil, the results were $91 \pm 0.9 \%$ FFAs at 48 hours and 93 $\pm 0.8 \%$ at 72 hours. The reaction with $62 \%(\mathrm{v} / \mathrm{v})$ soybean oil yielded $87 \pm 0.5 \%$ FFAs at 48 hours and $86 \pm 0.6 \%$ 
at 72 hours. Although both substrate concentrations gave similar results at 24 hours reaction time (Figure 7 ), the $50 \%$ concentration led to higher concentrations over longer times.

Subsequently, the use of distilled water instead of buffer was evaluated, in order to reduce the cost of the process. The reaction was carried out with 50\% soybean oil in the same reaction conditions as described above, and we obtained 84 $\pm 0.6 \%$ FFAs at 24 hours, $89 \pm 0.3 \%$ at 48 hours, and 90 $\pm 0.1 \%$ at 72 hours. The reaction with distilled water gave practically the same result as the reaction carried out in the buffer, so it was selected as the best option to be added to the reaction medium.

Thus, the selected conditions for soybean oil hydrolysis by lipase TL $100 \mathrm{~L}$ were $50 \%$ (v/v) soybean oil, distilled water, $2.3 \%(\mathrm{v} / \mathrm{v})$ lipase (corresponding to $25 \mathrm{U} / \mathrm{mL}$ of reaction medium), $60^{\circ} \mathrm{C}$, and 48 hours. Under these conditions, we obtained $89 \%$ hydrolysis.

This study is exceptional among enzymatic hydrolysis studies in the literature, in combining the high oil content with the low concentration of lipase, the use of aqueous media with no buffer, no organic solvent, and no emulsifier, which makes the reaction and purification steps easier and less costly (very important for a low value product as it is the biodiesel).

Freitas et al. [29] obtained 70 and 53\% soybean oil hydrolysis using lipases from Candida rugosa and Thermomyces lanuginosus, respectively. In addition to obtaining lower conversion rates, these authors used an oil content of $25 \%$, half that used in the present study, and $2.5 \%$ gum Arabic (emulsifier). In the study of Park et al. [30], combinations of lipase from Penicillium sp. $+R$. niveus and Penicillium sp. $+R$. delemar hydrolyzed up to $95 \%-98 \%$ of the soybean oil; the reaction was conducted with $3 \mathrm{~g}$ oil and $4 \mathrm{~mL}$ buffer for 10 hours. Park and colleagues used two lipases, whereas we used only one and did not use a buffer.

Talukder et al. [7] obtained complete hydrolysis of crude palm oil, but they used 33\% oil, 33\% organic solvent (isooctane), and a buffer in the reaction medium. Edwinoliver et al. [31] obtained a palm oil hydrolytic rate of $89 \%$ with a reaction medium containing $1 \mathrm{~g}$ oil in $20 \mathrm{~mL}$ buffer; in this case, the oil content was very low and they also used a buffer. In the study by Noor et al. [32], nearly all the palm oil was hydrolyzed in only 1.5 hours, but they employed an oil concentration of approximately $2.5 \%$ and an emulsifier.

In the study by Goswami et al. [33], castor oil was $60 \%$ hydrolyzed by Candida rugosa lipase, employing a 3:1 buffer phase volume to oil weight ratio. This is a lower oil content than that used in the present study, and also made use of a buffer, although they achieved a good reaction time of 6 hours.

Our research group [11] obtained complete hydrolysis of physic nut (Jatropha curcas) oil catalyzed by the lipase from its own seed. The reaction was conducted with $50 \%$ oil and $2.5 \%$ crude extract containing lipase, without adding organic solvent or emulsifier, although a buffer was used. Another promising study, by Talukder et al. [15], on the hydrolysis of waste cooking oil by Candida rugosa lipase, achieved complete conversion after 10 hours at an oil concentration of
$50 \%$ and lipase concentration of $0.025 \%$, without additives to the reaction medium (water).

Some studies have employed even more complicated techniques in enzymatic hydrolysis, such as ultrasound [34, 35] and supercritical $\mathrm{CO}_{2}$ [36] to increase the oil-water interface area where the lipase acts.

3.2. Esterification of FFAs to Biodiesel. After the hydrolysis of soybean oil with lipase TL 100L (under the optimum conditions described above), the esterification of FFAs with methanol and ethanol was carried out, catalyzed by niobic acid in pellets or without a catalyst. The results are shown in Table 3.

Based on the data presented in Table 3, the best esterification rate was $92 \%$, using methanol as the alcohol and niobic acid as the catalyst.

The higher reactivity of methanol compared to ethanol can be observed with and without the catalyst (Table 3). Similar behavior was observed by Aranda et al. [6] in the esterification of FFAs from palm oil using heterogeneous acid catalysts; they obtained up to $70 \%$ lower conversion rates using ethanol instead of methanol. Steric hindrance inherent to both the carboxylic acid and the alcohol species seems to be important, making reaction with methanol (a smaller molecule) faster, especially with heterogeneous catalysts [6]. Furthermore, the anhydrous ethanol has much more water than anhydrous methanol, and the water acts to shift the reaction equilibrium toward hydrolysis rather than esterification [14]. Although ethanol has some advantages, such as being a renewable resource and having low toxicity, as opposed to methanol, the latter is still widely used in biodiesel production due to its higher reactivity and lower cost $[5,37]$.

The niobic acid catalyst had a positive effect on the conversion of the esterification reaction of FFAs, giving $10.4 \%$ and $6.0 \%$ higher conversions with methanol and ethanol, respectively (Table 3 ). Because it is a heterogeneous catalyst, niobic acid in pellets can be easily separated from the product and reused.

Aranda et al. [6] evaluated the esterification of palmoil FFAs with methanol, using different heterogeneous catalysts and obtained conversion rates similar to those in this study. Talukder et al. [15] used Amberlyst 15 as a catalyst for biodiesel production by esterification of FFAs from waste cooking oil with methanol, and obtained 99\% esterification; however, they added an organic solvent to the reaction medium, which increases the cost of reagents and the purification process. Lima [9] studied biodiesel production from soybean and castor bean oils, using the process of hydroesterification catalyzed by niobic acid in pellets, and obtained conversion rates of $84 \%$ for the reaction of hydrolysis of soybean oil and $82 \%$ for castor bean oil; for the esterification reactions, the highest conversion rates were $92 \%$ for FFAs from soybean oil and $87 \%$ for those of castor bean oil. In the present study, we obtained higher conversion rates $(89 \%)$ for the hydrolysis reaction of soybean oil catalyzed by lipase TL 100L, and a similar conversion rate (92\%) for the esterification reaction of FFAs. 
TABlE 3: Esterification reactions of FFAs of soybean oil. The reactions were carried out using a molar ratio of FFAs/alcohol of $1: 3$ for methanol and 1:4 for ethanol, 20\% (w/w of FFAs) of the catalyst niobic acid in pellets, at $200^{\circ} \mathrm{C}$ and 1 hour reaction time.

\begin{tabular}{llccc}
\hline Alcohol & Catalyst & \multicolumn{2}{c}{ FFAs \% (w/w) } & Conversion* \\
& & Initial & Final & \\
\hline \multirow{2}{*}{ Methanol } & No & $90.6 \%$ & $15.1 \%$ & $83.3 \%$ \\
& Yes & $91.3 \%$ & $7.3 \%$ & $92.0 \%$ \\
\multirow{2}{*}{ Ethanol } & No & $90.6 \%$ & $19.9 \%$ & $78.0 \%$ \\
& Yes & $91.3 \%$ & $15.8 \%$ & $82.7 \%$ \\
\hline
\end{tabular}

* Conversion was calculated based on the initial concentration of FFAs.

\section{Conclusion}

The process of biodiesel production through the enzymechemical hydroesterification route catalyzed by Thermomyces lanuginosus lipase and niobic acid in pellets yielded 89\% FFAs in the hydrolysis reaction of soybean oil, and $92 \%$ of these FFAs were esterified to biodiesel.

The hydrolysis reaction was carried out with a low lipase concentration (2.3\%) and high oil concentration (50\%), in simple aqueous medium without a buffer, emulsifier, or solvent, to lower the cost of the process. In the esterification reaction, we also used a solvent-free medium with high substrate concentration (75\% FFA). The use of a heterogeneous catalyst, which can be easily separated and reused, also reduced the cost of the process.

The enzymatic-chemical hydroesterification appears to be a promising alternative to the traditional process of biodiesel production by alkaline transesterification.

\section{Acknowledgments}

This research received financial support from FAPERJ, $\mathrm{CNPq}$, and Petrobras.

\section{References}

[1] A. K. Agarwal, "Biofuels (alcohols and biodiesel) applications as fuels for internal combustion engines," Progress in Energy and Combustion Science, vol. 33, no. 3, pp. 233-271, 2007.

[2] D. A. G. Aranda, O. A. C. Antunes, D. M. G. Freire, R. C. A. Lago, E. D. C. Cavalcanti, and J. S. Sousa, "Produção de ácidos graxos catalisada por lipases não purificadas de sementes ou frutos vegetais para subseqüente esterificação por catálise ácida," PI0603824-7, 2006.

[3] L. F. Sotoft, B.-G. Rong, K. V. Christensen, and B. Norddahl, "Process simulation and economical evaluation of enzymatic biodiesel production plant," Bioresource Technology, vol. 101, no. 14, pp. 5266-5274, 2010.

[4] Y. Zhang, M. A. Dubé, D. D. McLean, and M. Kates, "Biodiesel production from waste cooking oil: 2. Economic assessment and sensitivity analysis," Bioresource Technology, vol. 90, no. 3, pp. 229-240, 2003.

[5] A. P. G. Encarnação, Geração de biodiesel pelos processos de transesterificação e hidroesterificação-uma avaliação econômica, M.S. thesis, Universidade Federal do Rio de Janeiro, Rio de Janeiro, Brazil, 2008.
[6] D. A. G. Aranda, J. A. De Goncalves, J. S. Peres et al., "The use of acids, niobium oxide, and zeolite catalysts for esterification reactions," Journal of Physical Organic Chemistry, vol. 22, no. 7, pp. 709-716, 2009.

[7] Md. M.R. Talukder, J. C. Wu, N. M. Fen, and Y. L.S. Melissa, "Two-step lipase catalysis for production of biodiesel," Biochemical Engineering Journal, vol. 49, no. 2, pp. 207-212, 2010.

[8] E. Minami and S. Saka, "Kinetics of hydrolysis and methyl esterification for biodiesel production in two-step supercritical methanol process," Fuel, vol. 85, no. 17-18, pp. 2479-2483, 2006.

[9] L. L. Lima, Produção de biodiesel a partir da hidroesterificação dos óleos dos óleos de mamona e soja, M.S. thesis, Universidade Federal do Rio de Janeiro, Rio de Janeiro, Brazil, 2007.

[10] J. A. Gonçalves, L. L. L. Rocha, A. K. Domingos, R. G. Jordão, F. R. Abreu, and D. A. G. Aranda, "Análise de reatividade e modelagem empírica da esterificação de compostos modelos sobre ácido nióbico para produção de biodiesel," in Proceedings of the 2nd Congresso da Rede Brasileira de Tecnologia de Biodiesel, Brasília, Brazil, 2007.

[11] J. S. de Sousa, E. d. Cavalcanti-Oliveira, D. A.G. Aranda, and D. M.G. Freire, "Application of lipase from the physic nut (Jatropha curcas L.) to a new hybrid (enzyme/chemical) hydroesterification process for biodiesel production," Journal of Molecular Catalysis B, vol. 65, no. 1-4, pp. 133-137, 2010.

[12] W. Du, W. Li, T. Sun, X. Chen, and D. Liu, "Perspectives for biotechnological production of biodiesel and impacts," Applied Microbiology and Biotechnology, vol. 79, no. 3, pp. 331337, 2008.

[13] M. Szczesna Antczak, A. Kubiak, T. Antczak, and S. Bielecki, "Enzymatic biodiesel synthesis-key factors affecting efficiency of the process," Renewable Energy, vol. 34, no. 5, pp. 1185-1194, 2009.

[14] M. Canakci and J. Van Gerpen, "Biodiesel production from oils and fats with high free fatty acids," Transactions of the American Society of Agricultural Engineers, vol. 44, no. 6, pp. 1429-1436, 2001.

[15] Md. M. R. Talukder, J. C. Wu, and L. P.-L. Chua, "Conversion of waste cooking oil to biodiesel via enzymatic hydrolysis followed by chemical esterification," Energy and Fuels, vol. 24, no. 3, pp. 2016-2019, 2010.

[16] http://www.novozymes.com/.

[17] M. L. M. Fernandes, N. Krieger, A. M. Baron, P. P. Zamora, L. P. Ramos, and D. A. Mitchell, "Hydrolysis and synthesis reactions catalysed by Thermomyces lanuginosa lipase in the AOT/Isooctane reversed micellar system," Journal of Molecular Catalysis B, vol. 30, no. 1, pp. 43-49, 2004.

[18] G. E. Crooks, G. D. Rees, B. H. Robinson, M. Svensson, and G. R. Stephenson, "Comparison of hydrolysis and esterification behavior of Humicola lanuginosa and Rhizomucor miehei lipases in AOT-stabilized water-in-oil microemulsions: II. Effect of temperature on reaction kinetics and general considerations of stability and productivity," Biotechnology and Bioengineering, vol. 48, no. 3, pp. 190-196, 1995.

[19] E. Jurado, V. Bravo, J. Núñez-Olea et al., "Enzyme-based detergent formulas for fatty soils and hard surfaces in a continuous-flow device," Journal of Surfactants and Detergents, vol. 9, no. 1, pp. 83-90, 2006.

[20] Y. H. Chew, L. S. Chua, K. K. Cheng, M. R. Sarmidi, R. A. Aziz, and C. T. Lee, "Kinetic study on the hydrolysis of palm olein using immobilized lipase," Biochemical Engineering Journal, vol. 39, no. 3, pp. 516-520, 2008. 
[21] M. A. Alim, J.-H. Lee, C. C. Akoh et al., "Enzymatic transesterification of fractionated rice bran oil with conjugated linoleic acid: optimization by response surface methodology," LWT, vol. 41, no. 5, pp. 764-770, 2008.

[22] R. Fernandez-Lafuente, "Lipase from Thermomyces lanuginosus: uses and prospects as an industrial biocatalyst," Journal of Molecular Catalysis B, vol. 62, no. 3-4, pp. 197-212, 2010.

[23] W. Li, W. Du, Q. Li, T. Sun, and D. Liu, "Study on acyl migration kinetics of partial glycerides: dependence on temperature and water activity," Journal of Molecular Catalysis $B$, vol. 63, no. 1-2, pp. 17-22, 2010.

[24] D.-C. Li, Y. I.-J. Yang, and C.-Y. Shen, "Protease production by the thermophilic fungus Thermomyces lanuginosus," Mycological Research, vol. 101, no. 1, pp. 18-22, 1997.

[25] S. S. Kumar and P. Palanivelu, "Purification and characterization of an extracellular polygalacturonase from the thermophilic fungus, Thermomyces lanuginosus," World Journal of Microbiology and Biotechnology, vol. 15, no. 5, pp. 643-646, 1999.

[26] S. Singh, P. Reddy, J. Haarhoff et al., "Relatedness of Thermomyces lanuginosus strains producing a thermostable xylanase," Journal of Biotechnology, vol. 81, no. 2-3, pp. 119128,2000

[27] Q. D. Nguyen, J. M. Rezessy-Szabó, M. Claeyssens, I. Stals, and Á. Hoschke, "Purification and characterisation of amylolytic enzymes from thermophilic fungus Thermomyces lanuginosus strain ATCC 34626," Enzyme and Microbial Technology, vol. 31, no. 3, pp. 345-352, 2002.

[28] E. Gomes, S. R. De Souza, R. P. Grandi, and R. D. Silva, "Production of thermostable glucoamylase by newly isolated Aspergillus flavus a 1.1 and Thermomyces lanuginosus a 13.37," Brazilian Journal of Microbiology, vol. 36, no. 1, pp. 75-82, 2005.

[29] L. Freitas, T. Bueno, V. H. Perez, J. C. Santos, and H. F. De Castro, "Enzymatic hydrolysis of soybean oil using lipase from different sources to yield concentrated of polyunsaturated fatty acids," World Journal of Microbiology and Biotechnology, vol. 23, no. 12, pp. 1725-1731, 2007.

[30] Y. K. Park, G. M. Pastore, and M. M. Almeida, "Hydrolysis of soybean oil by a combined lipase system," Journal of the American Oil Chemists' Society, vol. 65, pp. 252-254, 1988.

[31] N. G. Edwinoliver, K. Thirunavukarasu, S. Purushothaman, C. Rose, M. K. Gowthaman, and N. R. Kamtni, "Corn steep liquor as a nutrition adjunct for the production of Aspergillus niger lipase and hydrolysis of oils thereof," Journal of Agricultural and Food Chemistry, vol. 57, no. 22, pp. 1065810663, 2009.

[32] I. M. Noor, M. Hasan, and K. B. Ramachandran, "Effect of operating variables on the hydrolysis rate of palm oil by lipase," Process Biochemistry, vol. 39, no. 1, pp. 13-20, 2003.

[33] D. Goswami, J. K. Basu, and S. De, "Optimization of process variables in castor oil hydrolysis by Candida rugosa lipase with buffer as dispersion medium," Biotechnology and Bioprocess Engineering, vol. 14, no. 2, pp. 220-224, 2009.

[34] J. Huang, Y. Liu, Z. Song, Q. Jin, Y. Liu, and X. Wang, "Kinetic study on the effect of ultrasound on lipase-catalyzed hydrolysis of soy oil: study of the interfacial area and the initial rates," Ultrasonics Sonochemistry, vol. 17, no. 3, pp. 521-525, 2010.

[35] Y. Liu, Q. Jin, L. Shan, Y. Liu, W. Shen, and X. Wang, "The effect of ultrasound on lipase-catalyzed hydrolysis of soy oil in solvent-free system," Ultrasonics Sonochemistry, vol. 15, no. 4, pp. 402-407, 2008.
[36] M. Primožič, M. Habulin, and Ž. Knez, "Modeling of kinetics for the enzymatic hydrolysis of sunflower oil in a high-pressure reactor," JAOCS, Journal of the American Oil Chemists' Society, vol. 82, no. 8, pp. 543-547, 2005.

[37] A. Demirbas, "Biodiesel production from vegetable oils via catalytic and non-catalytic supercritical methanol transesterification methods," Progress in Energy and Combustion Science, vol. 31, no. 5-6, pp. 466-487, 2005. 

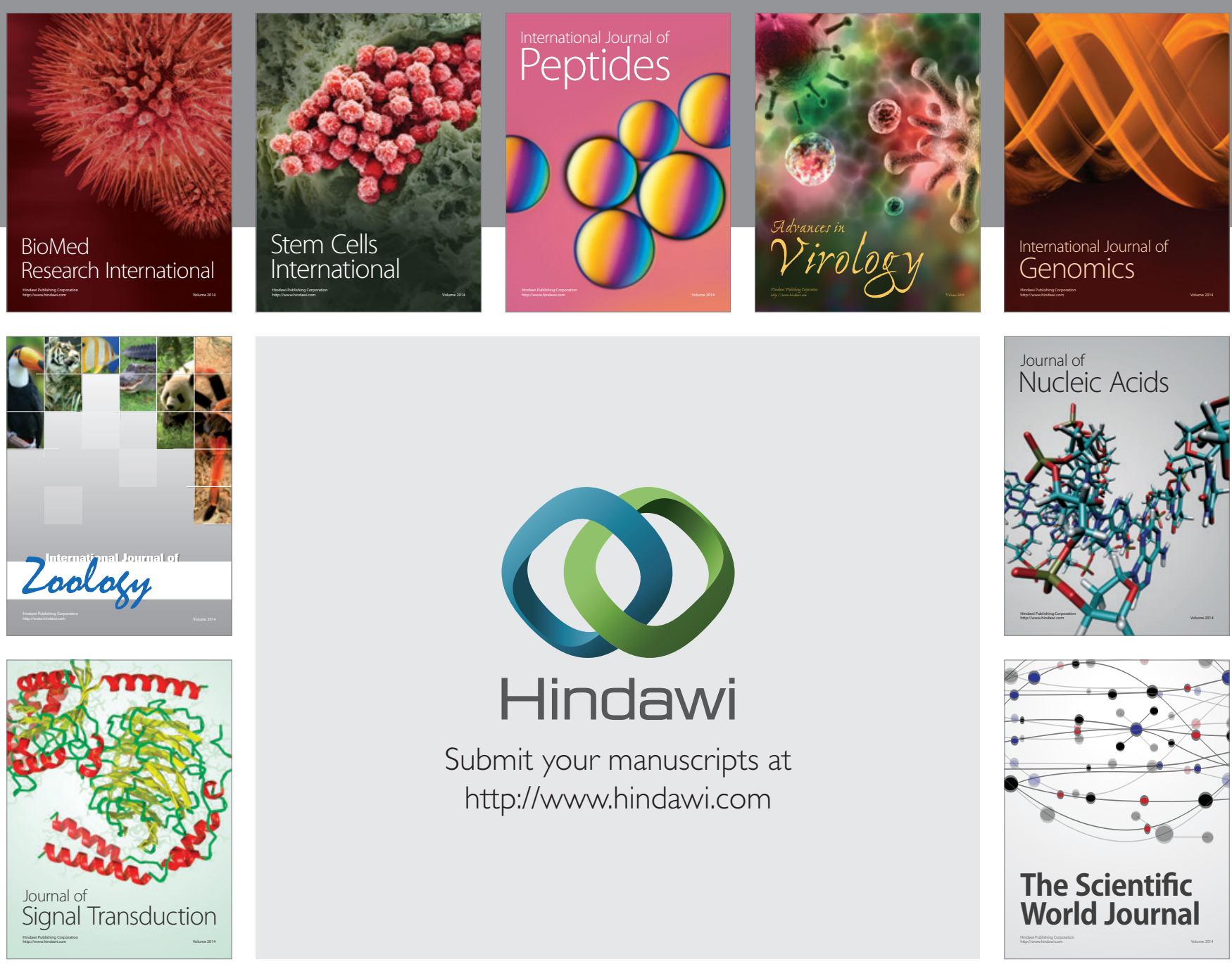

Submit your manuscripts at

http://www.hindawi.com
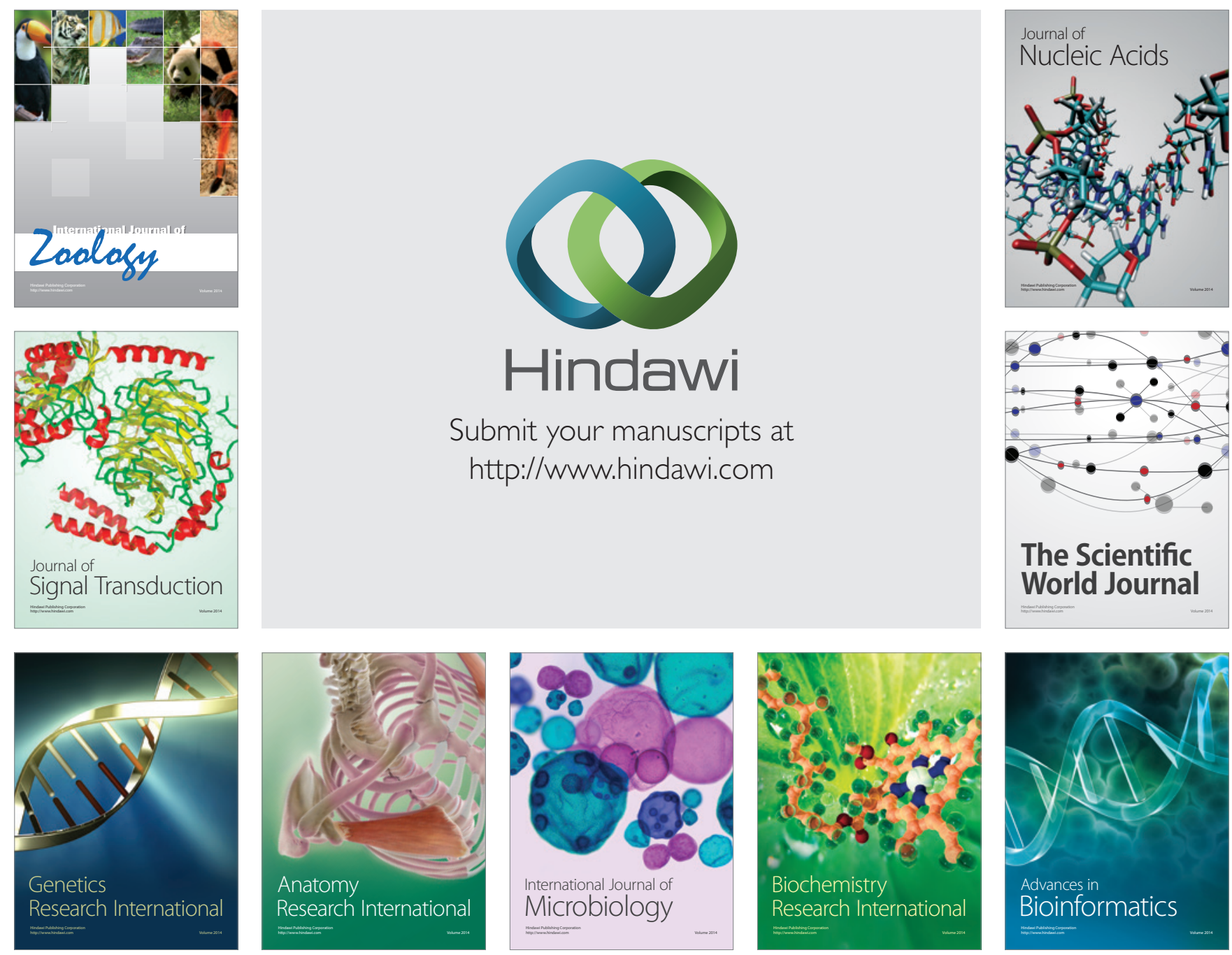

The Scientific World Journal
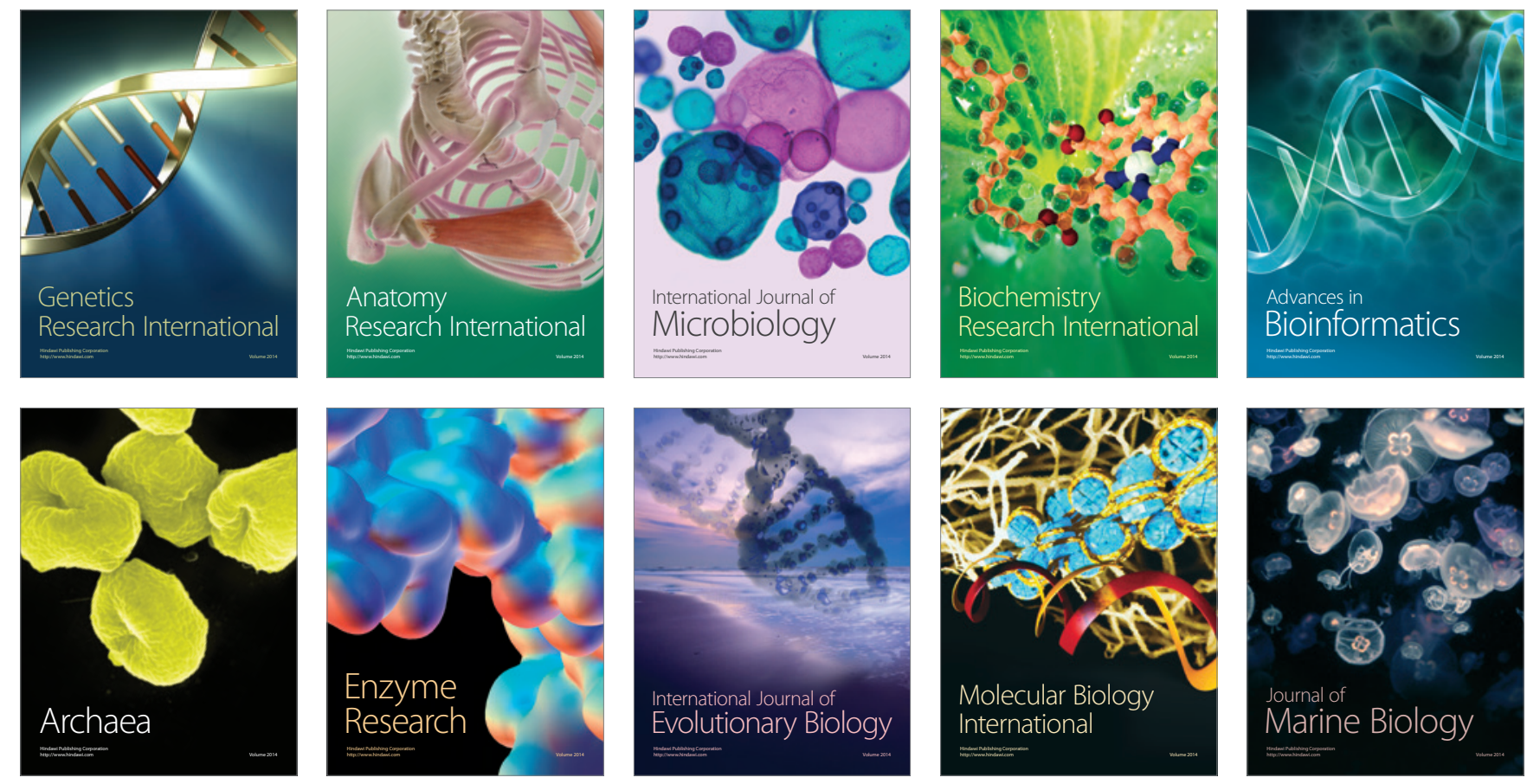